夢の材料ファクトリー“宇宙” 談話室

\section{微小重力環境実験を開始するに あたって}

20 世紀の後半の人類の科学技術の進歩は, その前半にも 増して目を見張るものがある．特に我々を取り巻く物質文明 は急速な発展を遂げているように思われる。しかし，これら の文化, 文明は地球表面, いいかえれば， $1 \mathrm{~g}$ の世界で起き る現象を基に発達し, 発展して来た. 然るに, 20 世紀後半 人類はロケット技術を手中に収め，宇宙空間といら微小重力 の新世界を垣間見ることが可能になった．我々にとってはユ ークリッドの世界から非ユークリッドの世界への開眼であ る.

私のように材料, 特に金属材料の溶解, 精錬, 凝固の研究 にたづさわっている者にとっては，微小重力下での物質の挙 動は新しい経験の連続であろう．特に量産材料の製造工程の 研究開発を長年経験して来た者にとっては全く予想もつかぬ 世界になりそうである，鉄鋼に例をとってみると，鉄鋼の精 錬工程に打いて, 脱硫, 脱燐, 脱酸工程などは, 何らかの形 で重力の存在を利用したものである．脱酸に例を採れば溶鋼 中の酸素の除去には $\mathrm{Al}_{2} \mathrm{O}_{3}$ を溶鋼中で生成させて浮上分離 させているのである. 仮に将来, 宇宙空間で精鍊を行うとす ればこの手法は使えず全く別な手法, 例えば電磁気を利用す るような方法を開発する必要があるであろう。また，合金を 製造する場合には，添加する金属間の比重の差を考慮した工

\footnotetext{
* 姫路工業大学教授; 工学部材料工学科 ( $\mathbf{7} 671-22$ 姫路市書写 2167)

Dreams of Investigation on Miner-gravity Nonvessel Solidification; Takasuke Mori(Department of Material Engineering, Faculty of Engineering, Himeji Institute of Technology, Himeji)

Keywords: solidification, nonvessel, miner-gravity, composite segregation, chill zone 1994年 4 月 4 日受理
}

程を組む必要もなくなり，非常に均質な合金溶湯の製造が可 能になるであろう，更にこれら溶製した溶湯を造型可能な金 属鋳塊を造る造塊凝固の工程では，凝固の進行に併い発現す る重力によるマクロ偏析の発生も起こらないであろらから， 鋳塊の何処の部分を採ってみても均質な性質を持つ鋳塊の製 造が可能になると考觉られる。しかし，鋳塊をマク口的に観 れば均質にはなってはいるが，凝固偏析によって生じる濃度 が徐々に異なってくる溶凝固組織がどのように分布するの か, 等々, 私達が地上といら常に重力が荷った環境での種々 の経験を基に描いた多くの疑問に対する回答が “宇宙”とい ら材料ファクトリーで回答が与えられることになる.

他方, 微小重力の世界を想定した材料作りにはどんなこと が考えられるのだろらか。 まず考觉られるのが比重が大きく 異なる材料を均一に分散させたよらな複合材料，例光ば $\mathrm{SiC}$ ゥスカーと銅のよらな組合せ，あるいは $\mathrm{W} と \mathrm{Al}$ のよ らな組合せなど，地上の溶解・凝固工程では創ることができ ない複合材創りへの夢は限りなく広がるのである.

昨今, 私が期待しているものに無容器凝固がある. 地上で の凝固のように鋳型を使わないため，金属本来の性質に基づ く自由表面での凝固組織を観察することが可能になるはずで ある.私の推測では，この自由表面の凝固組織は細かい網目 のようになっているはずである。ささすれば表面には非常に微 細でかつ多数の孔が存在し, その実表面積は広くかつ強い活 性を示すのではないかと考えられる。もしこれが正しけれ ば, 無容器凝固させた金属の表面は, 種々な用途を考劣るこ とができる。

現在我々の実験室では，重力を軽減した場合の金属の凝固 現象を追っている. 宇宙ラボの実験で起こる現象の中には地 上の経験からのみでは全く予想しにくいこともあると考えら れる，そこで地上と宇宙の間を結ぶ方法として，凝固時に重 力の大きさを $1 / 2 g, 1 / 3 g, 1 / 4 g$ 等に変えれば，その先に宇 宙がみえてくるのではないかと考劣て実験を開始した．試料 に荷る重力の大きさを変える，いいかえれば試料を無容器凝 固させる媒体，例えば空気等のガス体から水のような液体ま で種々の中間の密度を持つ冷媒を使うことを考えて居る.

最期に，私の夢は “宇宙ファクトリー”で新機能を持つ材 料が開発されたら，これと同じ機能を持つ材料を地球上で作 るためにはどのよらにすればよいのかを明らかにすることで ある。

いずれにしても，宇宙といら，人類がこれ迄経験したこと のない空間でしか実現不可能な材料の特性を識ることによっ て, 金属材料のみならず材料一般の新たなる特性の開発研究 に継げることができればといらのが私の材料ファクトリー “宇宙”への参加の弁である. 